\title{
Analisis Kegiatan Orang Tua Di Rumah Dalam Mengembangkan Kecerdasan Logika Matematika Aanak Usia 5-6 Tahun Di RA Hamdaniyah Tahun Ajaran 2021/2022
}

\author{
Elvida Rahayu Siagian \\ (1) Mahasiswa Program Studi PG PAUD FIP UNIMED \\ ${ }^{(2)}$ Dosen PG PAUD FIP UNIMED \\ J1. Williem Iskandar Pasar V Medan Estate, Medan, Sumatera Utara, 20371 \\ Email : elvida@gmail.com
}

\begin{abstract}
Abstrak: Penelitian ini bertujuan untuk menganalisis kegiatan orang tua dalam mengembangkan kecerdasan logika matematika di RA Hamdaniyah. Adapun indikator kegiatan orang tua di rumah pada penelitian ini adalah kegiatan memasak, mencuci, merapikan barang di rumah, menonton televisi, menanam bunga, bercerita dan indikator kecerdasan logika matematika pada penelitian ini adalah menunjukan empat sampai enam warna, menghitung sampai bilangan sepuluh, rentang perhatian yang lebih panjang, pemahaman konsep fungsi benda dan pemahaman konsep waktu berkembang. Penelitian ini dilaksanakan di RA Hamdaniyah Medan Tembung Sumatra Utara pada semester ganjil tahun ajaran 2021/2022. Metode penelitian ini adalah deskriptif kuantitatif. Populasi penelitian terdiri siswa RA Hamdaniyah semester ganjil 2021 yang berjumlah 40 orang. Sampel berjumlah 30 anak terdiri dari 15 anak perenpuan dan 15 anak laki-laki. Teknik pengumpulan data pada penelitian ini menggunakan observasi dan angket. Observasi dilakukan dilakukan di dalam dan di luar kelas saat pembelajaran maupun di luar pembelajaran. Observasi menggunakan lembar observasi dengan model checklist. Angket menggunakan lembar angket dengan model Guttman. Hasil penelitian menunjukan bahwa sebanyak 20 orang tua dengan hasil persentase $66,7 \%$ melakukan dalam bentuk kegiatan memasak, mencuci, merapikan barang didalam rumah dan menanam bunga. Sebanyak 6 orang tua dengan hasil persentase $20 \%$ melakukan dalam bentuk kegiatan bercerita dan sebanyak 4 orang tua dengan hasil persentase $13.3 \%$ melakukan dalam bentuk kegiatan menonton televisi dalam mengembangkan kecerdasan logika matematika.
\end{abstract}

Kata kunci: Kegiatan Orang tua di Rumah, Kecerdasan Logika Matematika 


\section{Pendahuluan}

Didalam aspek kognitif terdapat kecerdasan yang dapat dikembangkan dan menjadi perhatian orang tua untuk melaksanakan bermain sambil belajar atau proses pembelajaran. Kecerdasan terdapat 8 jenis yaitu kecerdasan linguistik, kecerdasan visual-spasial, kecerdasan logika matematika, kecerdasan intrapersonal, kecerdasan kinestetik, kecerdasan interpersonal, kecerdasan natural dan kecerdasan spiritual. Salah satu kecerdasan yaitu kecerdasan logika matematika yang terdapat pada aspek kognitif adalah mengenal warna, mengurutkan benda dari terbesar hingga terkecil atau sebaliknya, mengenal lambang bilangan, membedakan ukuran pendek, panjang, rendah dan tinggi.

Pembelajaran yang dilakukan di rumah pada anak usia dini yang dapat diperhatikan yaitu materi pembelajaran dan metode pembelajaran dengan belajar sambil bermain. Kegiatan bermain merupakan kegiatan yang dapat dilakukan secara alami (natural) dan sangat penting karena dapat mengembangkan semua aspek perkembangannya terutama dalam aspek kognitif terdapat dibagian kecerdasan logika matematika. Kecerdasan logika matematika adalah kemampuan yang melibatkan penalaran dengan baik dan mengelolah angka dengan benar. Kecerdasan logika matematika meliputi penalaran akan informasi yang didapatkan, memiliki kepekaan akan sebab-akibat, pengambilanakan keputusan dan memberikan kesimpulan. Menurut Purnama, dkk (2019 : 66) yang menyatakan anak yang memiliki kecerdasan logika matematika adalah "anak mampu mengurutkan bilangan 1 hingga minimal 50, senang dengan permainan utak-atik bilangan, menyukai permainan dalam komputer dan dengan muda meletakan benda sesuai dengan kelompoknya". Kecerdasan logika matematika dikembangkan sejak anak usia dini dalam bentuk kegiatan sehari-hari dapat dilakukan oleh orang tua karena akan mempengaruhi kecerdasan logika matematika anak dan kehidupan anak dimasa yang akan datang.

Kegiatan orang tua di rumah yang mengembangkan kecerdasan logika metematika dapat dilakukan dengan sederhana yaitu menggunakan media yang kogkret yang ada di dalam rumah, aman dan sesuai tahap perkembangan usia anak yang dapat memberikan stimulasi agar kegiatan pembelajaran dapat tercapai sesuai dengan yang diinginkan. Dalam kegiatan pembelajaran anak di rumah perlu kondisi yang kondusif, nyaman dan aman. Dalam mengembangkan kecerdasan logika matematika pada anak usia dini harus dilakukan secara terus menerus karena tidak dapat dilakukan secara cepat, perlunya adanya upaya dan kesabaran orang tua menciptakan bentuk kegiatan yang menyenagkan dan fasilitas di rumah untuk mendukung proses pembelajaran.

Pembelajaran yang dilakukan dalam kegiatan orang tua di rumah dan menjadikan orang tua sebagai guru yang bertanggungjawab menciptakan rasa aman nyaman dan 
sebagai fasilitator, meningkatkan motivasi, memberikan perhatian, penghargaan dan hukuman. Menciptakan kegiatan belajar di rumah yang menyenagkan dapat dilakukan dengan belajar sambil bermain dengan menggunakan strategi dan metode yang menarik agar anak mau untuk belajar dengan melakukan kegiatan di rumah dalam mengembangkan kecerdasan logika matematika, memberikan fasilitas yang dapat mengembangkan kecerdasan logika matematika, membuat anak tidak mudah bosan atau jenuh dan meningkatkan motivasi anak dalam pembelajaran logika matematika dalam bentuk kegiatan di rumah. Penghargaan akan capaian yang diperoleh anak dengan bentuk hadiah dan pujian. Memberikan hukuman atau sangsi kepada anak dengan memberikan penjelasan kepada anak bahwa yang dilakukannya salah, membuat larangan, dan peringatan.

Setiap orang tua pasti mempunyai harapan besar kepada anaknya, maka akan memberikan hal yang terbaik untuk masa depannya, sehingga dapat menjadi kebanggaan dikeluarga. Salah satu keinginan orang tua yang besar pada anaknya supaya anaknya mempunyai kemampuan dalam bidang logika matematika karena dalam dunia kerja dan kehidupan sehari-hari sangat dibutuhkan kemampuan tersebut. Kegiatan belajar dan bermain anak dapat mengembangkan seluruh aspek perkembangan anak. Menciptakan kegiatan yang dilakukan sehari-hari di rumah yang menarik minat bakat anak dalam belajar dan mengenal logika matematika. Bentuk kegiatan orang tua di rumah seperti kegiatan memasak, mencuci baju, , membersikan rumah, menonton televisi, merawat tanaman dan peliharaan, beribadah dan istirahat. Kegiatan orang tua di rumah dapat juga mengembangkan kecerdasan logika matematika dengan melakukan latihan menghitung apapun yang ada dirumah, memperkenalkan pola dengan benda-benda yang ada, melakukan eksperimen sederhana di rumah, mengajak anak untuk melihat cuaca dan mengobservasi lewat panca indranya, megajarkan hubungan sebab-akibat, mengajarkan anak untuk mengambil keputusan sejak dini, mengajak anak untuk memperkenalkan konsep harga dan memberikan penjelasan sesuai dengan fungsi dan kegunaannya, mengasah kepekaan akan keteraturan waktu.

Berdasarkan observasi yang dilakukan menunjukan 40 orang anak terdapat. 30 yang masih kurang dalam kecerdasan logika matematikanya, sedangkan 10 anak dalam kecerdasan logika matematika sudah berkembang dengan baik. Pada anak yang masih kurang dalam kecerdasan logika matematika yaitu belum mampu mengenal konsep angka, belum mampu untuk memahami konsep waktu yang berkembang, belum mampu mengenal bentuk-bentuk geometri dan pola sederhana, belum mampu untuk mengurutkan barang dari yang terbesar hingga terkecil atau sebaliknya, belum mampu untuk mencocokan benda berdasarkan warna, bentuk, dan ukuran, kurang mampu untuk menyimpulkan akan suatu informasi yang diperoleh, kurang mampu untuk menghitung angka dan kurang mampu menyelesaikan masalah secara sederhana. 
Sejalan dengan penelitian yang telah dilakukan oleh Cahyati dkk (2020, h. 155-156) berjudul Peran orang tua dalam menerapkan pembelajaran di rumah saat pademi covid 19 menyatakan bahwa "pembelajaran di rumah dinilai mampu meningkatkan kualitas pembelajaran, namun kurang menguntungkan untuk orang tua karena kurangnya interaksi siswa dengan guru dan teman-temannya".

\section{Metodologi}

Jenis penelitian yang akan digunakan adalah metode penelitian deskriptif kuantitatif. Penelitian dilakukan di RA Hamdaniyah Jalan Kemenangan No. 154 Kelurahan Indra Kasih, Kecamatan Medan Tembung, Kabupaten Deli Serdang. Waktu penelitian dilakukan pada bulan 06 Juli 2021 hingga 06 September Tahun 2021. Cara pengumpulan data pada penelitian ini menggunakan angket. Adapun teknik pengumpulan data yang digunakan dalam penelitian ini adalah observasi, angket dan dokumentasi dengan mengunjungi rumah setiap orang tua siswa. Penelitian ini menggunakan teknik deskriptif kuantitatif.

\section{Hasil dan Pembahasana}

Bentuk kecerdasan kegiatan orang tua di rumah dalam mengembangkan kecerdasan logika matematika pada sampel penelitian sebanyak 30 orang anak usia 5-6 tahun dapat dilihat dari analisis data angket dan didukung oleh hasil observasi yang dilakukan di lapangan. Adapun indikator kecerdasan logika matematika yang sudah dijelaskan pada Tabel 3.2. yaitu kisi-kisi instrumen yang diambil dari pendapat Yus (2011, h.71). Persentase yang diperoleh per indikator dengan jumlah keseluruhan anak setelah dihitung adalah: a) Indikator kemampuan memberi nama benda yang dikelompokan sesuai empat sampai enam warna sebanyak 22 anak $(73,3 \%)$ kategori "baik". 2) Menghitung satu sampai bilangan sepuluh sebanyak 23 anak (76,7\%) kategori "sangat baik". 3) Rentang perhatian yang panjang sebanyak 16 anak $(53,6 \%)$ kategori "baik". 4) Pemahaman fungsi dari benda sebanyak 20 anak (66,7\%) kategori "baik". 5) Pemahaman konsep waktu yang berkembang sebanyak 19 anak (63,3\%) kategori "baik". Kelima indikator tersebut dapat terlihat kecerdasan logika matematika anak usia 5-6 tahun RA Hamdaniyah berada dalam kategori "baik".

Berdasarkan hasil angket bentuk-bentuk kegiatan orang tua di rumah dalam mengembangkan kecerdasan logika matematika usia 5-6 Tahun pada Tabel 3.3 yang diambil dari pendapat Hardywinoto (2005, h. 11) dan Yus (2011, h. 71). Diperoleh hasil per indikator dengan jumlah keseluruhan dengan indikator yaitu: 1) kegiatan memasak sebanyak 20 orang tua dengan hasil persentase $66,7 \%$ kategori "baik". 2) kegiatan mencuci sebanyak 20 orang tua dengan hasil persentase $66,7 \%$ 
kategori "baik". 3) kegiatan merapikan barang didalam rumah sebanyak 20 orang tua dengan hasil persentase $66,7 \%$ kategori "baik". 4) kegiatan memelihara tanaman bunga sebanyak 20 orang tua dengan hasil persentase $66,7 \%$ kategori "baik". 5) kegiatan menonton televisi sebanyak 4 orang tua dengan persentase 13,3\% kategori "kurang". 6) kegiatan bercerita sebanyak 6 orang tua dengan persentase $20 \%$ kategori "kurang".

Pembiasaan yang dilakukan pada anak untuk mengembangkan kecerdasan logika dalam bentuk kegiatan orang tua di rumah yang dapat dilakukan secara sederhana. Peneliti melihat bahwa kemampuan setiap anak yang berbeda-beda dari persentase yang diperoleh observasi yang telah dilakukan, namun masih banyak orang kurang memahami cara mengembangkan kecerdasan logika matematika anak dalam kegiatan sehari-hari.

Menurut Abdussalam (2014, h. 107) menyatakan "kecerdasan matematis logis adalah suatu kemampuan yang dimiliki seseorang untuk berpikir secara logis, rasional dan suka yang berbaur tentang angka-angka". Anak yang sudah mulai berkembang kecerdasaan logika matematika akan suka untuk bertanya secara kritis dan suka memecahkan suatu permasalahan sederhana.

Berdasarkan pendapat ahli diatas, dapat disimpulan bahwa kecerdasan logika matematika adalah suatu kemampuan yang dimiliki setiap manusia dalam cara memahami dan memperoleh informasi yang didapat baik secara cepat maupun lambat, menyimpulkan informasi yang diterima, memecahkan masalah sesuai dengan penalaran dan kemampuan dalam bidang angka. Kecerdasan logika matematika pada anak dengan mengenal konsep angka secara berurutan dan acak, penjumlahan, pengurangan, pengelompokan, serta dalam memecahkan masalah dapat menemukan solusi akan masalah yang dihadapi secara tepat dan logis.

Kecerdasan logika matematika dapat dikembangkan dalam bentuk kegiatan seharihari. Kegiatan yang dilakukan di rumah dapat dikaitkan dengan konsep angkaangka, hubungan sebab dan akibat untuk mengembangkan kecerdasan logika matematika baik secara terencana maupun tidak terencana. Berikut adalah kegiatan mengembangkan kecerdasan logika matematika.

Menurut Yus (2011, h. 71) kecerdasan logika matematika dapat dikembangkan dengan kemampuan yaitu :1) Bermain kata-kata, 2) menunjukan dan memberikan nama empat sampai enam warna, 3) mencocokan gambar dari objek yang sama, 4) menggambar orang dengan dua sampai empat bagian yang dikenal, 5) menggambar, menamai dan mendeskripsi gambar yang dikenal, 6) menghitung luar kepala sampai bilangan lima meniru orang dewasa, 7) mengenal posisi tempat tinggal, 8) memiliki rentang perhatian yang lebih panjang, belajar melalui pengamatan dan 
mendengarkan orang dewasa, 9) pemahaman konsep fungsi, waktu, persahabatan secara utuh dan bagian-bagian, 10) memiliki konsep waktu yang semakin berkembang.

Menurut Setyowati (2016, h. 132) kegiatan mengembangkan kecerdasan logika matematika yaitu :1) Melakukan eksplorasi dengan bebas sebuah pola dengan menekan benda atau benda-benda yang aman 2) melakukan eksperimen kecil di rumah, 3) melihat cuaca dan melakukan observasi lewat panca indranya, 4) mengenalkan hubungan sebab- akibat untuk mengasah logikanya, 5) menyebutkan dimensi dan ukuran benda-benda yang ada di sekitar kita, 6) berbelanja dan memperkenalkan konsep harga, 7) menonton tayangan bersifat ilmiah tentang penemuan, 8) bermain belanja-belanjaan dengan uang kertas yang dibuatnya sendiri, 9) anak pertanyan mengenai sesuatu menjadikan objek untuk observasi, 10) memberitahu secara detail boleh melakukan sesuatu atau tidak melakukan sesuatu, 10) Latihan menghitung apapun yang ada disekitar kita seperti menghitung anak tangga, menghitung pensil, kelereng, manik-manik. 11) memberi tahu melakukan sesuatu sesuai dengan fungsi dan kegunaannya.

Menurut Sujiono (2016, h. 187) mengembangkan kecerdasan logika matematika melalui permainan yaitu: 1) Bermain ular tangga, domino dan puzzel, 2) mengenalkan bentuk geometri dan mengelompokan sesuai dengan warna, bentuk dan jenis, 3) mengenalkan bilangan dengan bernyayi atau lagu-lagu anak, 4) eksplorasi pendapat melalui diskusi dan permainan teka-teki atau tebak kata, 5) mengenal pola dengan menyusun manik-manik atau kancing warna-warni, mengamati kejadian sehari-hari untuk mecermati sebab-akibatnya, 6) melakukan eksperimen di alam dengan mengajak anak untuk menanam tanaman dan bereksplorasi di alam, 7) memberikan pengalaman dan berinteraksi dengankonsep matematika, 8) membuat permainan dengan strategi untuk mengelompokkan benda, menyebutkan, mempelajari dan mengenal bilangan dengan permainan kartu angka.

Berdasarkan dari penjelasan diatas dapat disimpulkan bahwa kegiatan orang tua dalam mengembangkan kecerdasan logika adalah suatu tindakan untuk melakukan pengenalan konsep angka, bilangan, perhitungan secara sederhana dengan mengeksplorasi benda yang ada di rumah, mengajarkan konsep waktu dengan tepat waktu saatnya untuk istirahat, makan dan bermain, dan melakukan percobaan sederhana atau observasi cuaca menggunakan semua panca indra, mengemukakan alasan yang logis akan sebab dan akibat dari suatu permasalahan yang ditemukan dalam kehidupan sehari-hari.

\section{Kesimpulan}

Hasil kecerdasan logika matematika anak di sekolah RA Hamdaniyah berdasarkan penelitian yang dilakukan peneliti ini menunjukan bahwa sebagian besar anak 
berada pada kriteria Berkembang Sesuai Harapan (BSH) sebanyak 20 anak (66,7\%), terdapat anak dengan kriteria Mulai Berkembang (MB) sebanyak 10 anak (33,3\%). Dapat diketahui bahwa kecerdasan logika matematika anak di sekolah RA Hamdaniyah sudah berada pada kategori baik.

Hasil dari angket diperoleh bentuk-bentuk kegiatan orang tua di rumah dalam mengembangkan kecerdasan logika terhadap anak menunjukan hasil persentase paling besar sebanyak 20 orang tua dari 30 orang dengan hasil persentase $66,7 \%$ orang tua dalam kegiatan memasak, mencuci, merapikan barang didalam rumah dan memelihara tanaman bunga. Sedangkan sebanyak 6 orang tua dengan persentase $20 \%$ bentuk kegiatan bercerita dan sebanyak 4 orang tua dengan persentase 13,3\% bentuk kegiatan menonton televisi dalam mengembangkan kecerdasan logika matematika.

\section{DAFTAR PUSTAKA}

Addussalam \& Subhi, M. (2014). Anakku Hebat Penuh Bakat. Solo: Tayiba Media.

Kusmayadi, I. (2016). Membongkar Kecerdasan Anak (Mendeteksi Bakat dan Potensi Anak Sejak Dini). Jakarta: Gudang Ilmu.

Purnama, S,. Hijriyani, Y. S., \& Heldanita. (2019). Pengembangan Alat Permainan Edukatif Anak Usia Dini. Bandung: Remaja Rosdakarya.

Setyowati, H. (2015). Aku Anak Cerdas. Jakarta: Elex Media Komputindo

Sujiono, Nurani, Y. (2016). Konsep dasar pendidikan anak usia dini. Jakarta: Indeks

Yus, A. (2011). Model Pendidikan Anak Usia Dini. Jakarta: Prenadamedia Grup.

Cahyati, N., \& Kusumah, R. (2020). Peran Orang Tua Dalam Menerapkan Pembelajaran Di Rumah Saat Pandemi Covid 19. Jurnal Golden Age, 4(1), 156. (Diakses tanggal 14 Juni 2021). 